\title{
Protecting Europe from Diseases: From the International Sanitary Conferences to the ECDC
}

\author{
Marco Liverani \\ Richard Coker \\ London School of Hygiene and Tropical Medicine
}

\begin{abstract}
In the past few decades there has been an increased integration of communicable disease policies in Europe. The historical roots of this process date back to the mid-nineteenth century, when national authorities realized that the crossboundary spread of diseases cannot be only a matter of national governance but requires common agreements and regulations. In the early 1950s the structuring of the World Health Organization in regional offices further contributed to the definition of Europe as a unit for risk assessments and international health cooperation. More recently the consolidation of the European Union has provided new institutional bases for shaping communicable disease policies at the supranational level. This article reviews these different attempts to protect the European space from diseases. It is argued that changing modes of communicable disease control have not only reflected shifts in public health priorities and institutional contexts but have also been important loci where different understandings of Europe and European political identity emerged and were negotiated. Against this background the article then examines past achievements and future challenges of the current European framework and discusses implications for the wider process of European integration.
\end{abstract}

Communicable disease control has a peculiar political logic. Because of the transnational spread of diseases, prevention and control measures have long challenged existing concepts of territorial sovereignty and required international cooperation. At the same time, the ways governments and

Some material in this article is derived from a research project commissioned by the AsiaEurope Foundation, whose support is gratefully acknowledged. The authors alone bear full responsibility for any information reported, interpretation, and the decision to submit for publication. The authors would also like to thank the anonymous reviewers for their valuable suggestions.

Journal of Health Politics, Policy and Law, Vol. 37, No. 6, December 2012 DOI $10.1215 / 03616878-1813772$ (C) 2012 by Duke University Press 
health authorities collaborate are inevitably shaped by the context of international relations, institutional dynamics, and the broader landscape of political culture. The historical development of communicable disease policies in Europe is a good case in point. In many ways, changing modes of European cooperation in public health have reflected contingent meanings of Europe and its relations with other parts of the world.

This article aims to shed some light on these issues by analyzing in historical perspective different attempts to protect the European space from communicable diseases, starting with the early International Sanitary Conventions of the nineteenth century to the recent involvement of the European Union (EU). In particular, we review the development of institutional frameworks that have provided the basis for international collaboration and how such processes have been affected by changes in political environments and shifting notions of European cooperation. Against this background, the second part of the article focuses on past achievements and future challenges of the current supranational system for communicable disease control, identifying key issues that might arise as the EU expands its competencies in this policy area.

\section{The Politics of Disease at the International Sanitary Conferences}

Early efforts at international collaboration for communicable disease control in Europe date back to the nineteenth century and were prompted by the threat of cholera. This disease had long been endemic in India in the Bengal region and the Ganges river delta (Hays 2005). In the period 1817-1824, however, the disease spread throughout India and then to many other areas in Asia and the Western Pacific. In 1827 a second pandemic again originated in the Bengal region, rapidly moving into the Russian Empire and from there to Prussia, France, England, and North America. A third pandemic wave hit Europe between 1848 and 1854. As the disease reached European cities, it took advantage of poor sanitation and unsafe water supply. About 61,000 people died In England in 1848-1849 and a further 26,000 in 1853-1854, 10,000 of those in London. In Paris 20,000 died of cholera in 1849 (Hays 2005). Because of the high mortality rate and its dramatic symptoms, cholera profoundly affected European societies and challenged public order and stability. Moreover, the disease was widely perceived as a transnational threat. As a commentary published in 1832 in the British periodical Quarterly Review noted, the disease "mas- 
tered every variety of climate, surmounted every natural obstacle, conquered every people" (Briggs 1961: 76)

In the face of this scourge, European governments initially responded with traditional containment measures. Since the Black Death of the fourteenth century, quarantine had been the standard policy for infectious disease control. Quarantine required ships coming from suspected or infected sites to stay at anchor for a month before docking. Likewise, land travelers were kept in isolation for about forty days in a place that was usually outside the city walls. In 1423 Venice set up one of the first known lazaretto (quarantine station) on an island near the city, and the Venetian system became a model for other European countries (Gensini et al. 2004).

However, during the nineteenth century quarantine and cordons sanitaires became increasingly contested. In many cities the mercantile elites staunchly opposed them. In a world where the rapid circulation of people and goods was increasingly crucial to commercial profit, quarantine policies were regarded as old-fashioned impediments to travel and trade - particularly because of the wide acceptance of medical theories of the time that denied the contagious nature of cholera (Ackerknecht 2009). Moreover, the fragmentation of regulations and containment practices across Europe was regarded as an additional burden to commerce as well as an obstacle to effective control of the disease (Maglen 2003).

Driven by the need for more uniform rules, in 1851 the delegates of twelve governments convened in Paris to discuss the bases for common agreements on quarantine and the containment of cholera. Despite six months of negotiations, this first International Sanitary Conference did not produce any substantial outcomes. However, it established a platform for international dialogue in this area, which was further consolidated through subsequent meetings and negotiations. Most notably, it led to the adoption of the first International Sanitary Convention in 1892 and other international treaties in the following decades (Howard-Jones 1975).

The history of these early efforts toward international cooperation is not only relevant as the background of current developments in international health and particularly the International Health Regulations (Fidler 2005); it also reflects wider issues of political culture and political economy. First, the International Sanitary Conferences were eminently political events. Unlike the scientific congresses of the same period, the sanitary conferences involved diplomats and other government officials, along with scientists and physicians. In this unusual space for political negotiation, various 
forms of nationalism counteracted the spirit of international collaboration. Agreements were often hard to achieve precisely because quarantine policies were closely associated with different national interests in commerce and trade protection. In addition, nationalist sentiments emerged in the scientific competition to conquer diseases, as the rivalry between Robert Koch and Louis Pasteur in the years of the Franco-Prussian War exemplifies (Brock 1999).

Second, a territorial and self-protective idea of Europe emerged from these early attempts to develop international communicable disease policies. Although cholera caused higher mortality rates in other regions of the world, European delegates at the sanitary conferences were primarily concerned with protecting the European space from what were seen as external threats. In particular, the Mecca pilgrimage was regarded as the prime cause of widespread contagion and became the target of unprecedented surveillance measures, despite its limited role in bringing cholera into Europe (Huber 2006).

Likewise, the passage in quarantine through the Suez Canal became a crucial strategic issue. Opened in 1869 , the Suez Canal allowed water transportation between Europe and Asia without navigating around Africa. At the same time, European authorities were worried that the canal might be a conduit for importing cholera from India to Europe. This problem was debated at several conferences, and in 1892 European governments signed the first International Sanitary Convention to define common procedures concerning the passage of ships through the canal. This pioneering document of international health law prescribed that all ships were to be classified according to different risk profiles. Those without any registered case of cholera could pass through the canal without stopping, but suspected ships could pass without inspection only if they informed the ports and if they had a doctor and a disinfecting machine on board. As Valeska Huber (2006: 467) points out, the fundamental idea was to create a "semi-permeable" border between the Orient and the Occident that "was open for commercial enterprises but closed for microbes and other suspicious elements."

\section{The WHO Regional Office for Europe}

The International Sanitary Conferences and resulting conventions laid down the bases of the modern framework for international health cooperation. In the early twentieth century the establishment of permanent offices and institutions, such as the International Sanitary Bureau of the 
American Republics (1902) and the Office International d'Hygiène Publique (OIHP) in Paris (1907), further contributed to these developments. In addition, in 1920 the League of Nations provided an important political platform to promote international efforts. While this organization was primarily aimed at supporting collective security and the peaceful resolution of conflicts, it was also required "to take steps in matters of international concern for the prevention and control of disease" (League of Nations 1920). To this purpose, its health section provided technical assistance to member governments, published epidemiological data and technical reports, and set up a number of committees on specific issues, such as the standardization of laboratory protocols, the prevention and control of malaria, and the international traffic in opium (Boudreau 1935; HowardJones 1950).

After the end of World War II, these efforts toward international cooperation were carried on by the United Nations and its health agency, the World Health Organization (WHO). WHO incorporated under its administration the former international health offices, including the International Sanitary Bureau (renamed the Pan-American Sanitary Organization and later the Pan American Health Organization), the League of Nations Health Organisation, the Office International d'Hygiène Publique, and the Conseil Sanitaire, Maritime et Quarantenaire in Alexandria, Egypt. Moreover, under Article 21 of the WHO constitution (WHO [1948]), the World Health Assembly was given the authority to issue a single set of binding rules on "sanitary and quarantine requirements and other procedures designed to prevent the international spread of disease," which were intended to rationalize the former patchwork of twelve sanitary conventions. As a result, in 1951 WHO adopted the International Sanitary Regulations, a new set of rules that, among other obligations, required member states to disclose information on four communicable diseases: cholera, yellow fever, smallpox, and plague. Similar to early agreements, these rules were partly driven by the global force of commerce - namely, the need to "ensure the maximum security against the international spread of disease with the minimum interference with world traffic" (WHO 1951: 5). In other respects, however, the new regime of international cooperation was remarkably different. Unlike the Eurocentric standpoint of the sanitary conventions, WHO had an explicit universalistic outlook. Indeed, the preamble of the WHO Constitution stated that "the enjoyment of the highest attainable standard of health is one of the fundamental rights of every human being without distinction of race, religion, political belief, economic or social condition" and "the health of all peoples is funda- 
mental to the attainment of peace and security and is dependent upon the fullest co-operation of individuals and States" (WHO [1948]). Over the years this global commitment has been reasserted in ambitious policy statements such as the Declaration of Alma-Ata and the WHO Health for All campaign, which emphasized the need for urgent action by governments, international organizations, and health authorities to protect and promote the health and well-being of all people in the world (WHO 1978).

While pursuing a global agenda, since its foundation WHO has always operated through a decentralized system of regional offices, which are responsible for the implementation of health programs in six wide geographic areas: Africa, the Americas, Southeast Asia, Europe, the Eastern Mediterranean, and the Western Pacific. In the European region, the WHO Special Office opened in Geneva in 1949 as a temporary agency to help reconstruct health services after the disasters of the war and to respond to tuberculosis epidemics. Several years later the temporary office was upgraded to the permanent Regional Office for Europe (WHO/ Europe), and the central bureau was moved to Copenhagen. As a recent account of these early developments documents (WHO 2010), international cooperation was one of the main concerns of its founding director, Norman Begg: "Europe not only had problems that needed immediate action - such as epidemics - but also needed to rebuild health care systems that, before their large-scale destruction, had been remarkably sophisticated. The best way to begin this effort to reconstruct the Region's health systems so that they were better than before, he believed, was to bring countries together - many of which had recently been enemies - in a spirit of mutual cooperation" (WHO 2010:10). This approach well combined with the wider set of institutional initiatives for international cooperation that were sustaining and shaping European reconstruction, such as the Organisation for European Economic Co-operation (1948), the Council of Europe (1949), and the European Coal and Steel Community (1951). These initiatives were established to foster the social and economic recovery of European countries, but they also had important political implications. On the one hand, they tried to prevent another conflict in Europe by creating closer links among former enemies; on the other, the reconstruction of Europe as a whole on the basis of democracy and with US backing was a way to prevent the expansion of Communism beyond the Iron Curtain. Indeed, the first major challenge to WHO universalism arose when Eastern Bloc countries resigned from WHO in 1949, resuming active membership only at the end of the 1950s (Lee 2009). 
Despite this shaky beginning, over the years WHO/Europe became a leading center for international health cooperation, providing technical assistance to member countries, collecting and analyzing data to inform public health interventions, and ensuring coherence and integration of regional activities with the overarching organization's global surveillance system and policy agenda (WHO 1958). From the end of the 1970s to the present, the Alma-Ata declaration on Health for All and subsequent policy documents based on principles of solidarity, equity, and participation (such as the 2008 Tallinn Charter) have guided regional programs and activities.

In keeping with these principles, in the past two decades WHO/Europe has developed many programs to improve access to essential health care in the eastern part of the region and address the dramatic rise in health burdens after the collapse of the Soviet system. To this aim, the regional office has established new liaison offices and in the 1990s launched Eurohealth, a comprehensive plan for the development of health care systems in the newly independent states, including human resources, maternal and child health, HIV/AIDS prevention, and environmental health (Danzon and Litvinov 1993). In addition, the emergence or reemergence of communicable diseases such as diphtheria and drug-resistant tuberculosis in the eastern countries, as well as global threats of severe acute respiratory syndrome (SARS) and pandemic influenza, led to new investments in disease surveillance. In 1998, for example, the regional office established the Computerized Information System for Infectious Diseases (CISID), which has substantially improved the sharing of routine information and alerts between research centers, institutions, and individual practitioners throughout the European region (MacLehose, McKee, and Weinberg 2002).

\section{Threats to the Union}

The consolidation of European integration through the European Community (EC) has provided another important institutional platform to shape communicable disease policies at the regional level. Early developments date back to the 1980 s, when research centers in EC member countries sought funding from the European Commission to set up surveillance networks to monitor and study specific diseases at the European level, including HIV/AIDS, tuberculosis, legionella infections, food-borne infections, and influenza. These early initiatives contributed to the analysis of epi- 
demiological trends and health resources in a wide geographic space, yet their implementation highlighted many discrepancies in diagnostic criteria and classification systems (Fleming and Cohen 1996; Fleming, van der Velden, and Paget 2003). As a result, in 1994 the heads of national surveillance centers established the Charter Group, an informal advisory body to set up a unified framework for disease surveillance in collaboration with the European Commission, leading to the production of a pan-European surveillance bulletin (Eurosurveillance) and a high-level training program in field epidemiology (the European Programme for Intervention Epidemiology Training [EPIET]) that aimed to form a cadre of senior epidemiologists sharing common methods and approaches.

Since the end of the 1990s these developments have increasingly been absorbed into the EU's legal and institutional framework (MacLehose, McKee, and Weinberg 2002; Reintjes 2008), which has considerably expanded the scope of early interventions. In 1998 the European Parliament and the European Council approved a formal decision to set up a European network for epidemiological surveillance and control (European Parliament and EU Council 1998). This included the Early Warning and Response System, which was meant to ensure rapid communication between member states and the commission in the event of public health emergencies of international concern (Guglielmetti et al. 2006). Moreover, while the actual response to public health threats largely remains a competence of member states, the legal bases for EC activities in this area have been strengthened, although in a rather unsystematic way and mainly through case law (McKee and Mossialos 2006; Greer 2008; Lamping and Steffen 2009). Finally, since 2005 the EU strategy on communicable diseases has been further consolidated with the establishment of the European Centre for Disease Prevention and Control (ECDC), an independent agency funded by the European Commission in order to "identify, assess and communicate current and emerging threats to human health from communicable diseases" (European Parliament and EU Council 2004). To fulfill its mandate, the ECDC performs a wide range of activities, including collecting, collating, and analyzing epidemiological data; providing scientific opinion, training, and technical assistance to member states; furnishing risk assessments to the commission, the member states, community agencies, and international organizations; and standardizing data collection and reporting practices.

In many ways the establishment of the ECDC marks a further step toward a more centralized approach (Liverani, Hanvoravongchai, and Coker 2012). While former initiatives were supported by the European 
Commission yet coordinated and managed by national authorities or research centers, the ECDC has gradually incorporated those functions into a single expert body, including maintaining the editorial office of Eurosurveillance, coordinating the EPIET, and managing the disease surveillance networks. This development, moreover, is part of a wider EU system for communicable disease control, in which the European Commission's Directorate-General for Health and Consumers (DG-SANCO) has a mandate to coordinate member states' operations in the event of public health threats on the basis of ECDC surveillance and risk assessment.

How can we explain these developments? Why have EU institutions become increasingly proactive in this policy area given the existence of other platforms for international health cooperation, namely the WHO Regional Office for Europe? Aware that policies result from the convergence of different factors and that it would be misleading to draw linear causal relations between "drivers" and policy making, we can identify a number of concomitant developments. First, the growing mobility of people and traded goods within the EU has facilitated the transnational spread of diseases and has thus required increased cooperation and the harmonization of surveillance procedures. This need became more urgent after the latest rounds of enlargement, which expanded the EU to twentyseven member states (McKee, MacLehose, and Nolte 2004). Second, recent public health crises of international concern, such as bovine spongiform encephalopathy with resultant Creutzfeldt-Jakob disease (commonly known as mad cow disease) in the 1990s, and subsequent threats from SARS, bioterrorism, and highly pathogenic avian influenza H5N1 provided further impetus to coordinate national efforts. But there are also other considerations, which once again reflect the wider context of political economy and culture in which policy programs and interventions are developed.

As the EU has moved from a primarily economic to a more political form of cooperation, the notion of "European citizen" has become more central to the whole project of European integration, although the legal and political contours of this emerging subject are still uncertain in terms of democratic participation. Most notably, in 1992 the Maastricht Treaty institutionalized the status of "citizenship of the Union" to strengthen and enhance European identity and enable Europeans to participate more actively in the EC's political life. In this context, health and safety have gained more prominence in EU activities and policy discourses. This change is exemplified by DG-SANCO's new role. Initially established as a technical agency to monitor the safety of traded goods, 
over the past decade DG-SANCO has reconceptualized its mission to help make Europe's citizens healthier, safer, and more confident (CEC 2005), including programs on disease prevention and control, the international mobility of patients, pharmaceutical safety, and reduction of health care inequalities across member countries. In addition, new strategic visions of EU health's new role have been articulated. For example, in 2007 the EC issued the White Paper "Together for Health," which identified the strategic objective of "protecting citizens from health threats" (CEC 2007: 8), including epidemics, bioterrorism, noncommunicable diseases, accidents, and work injuries.

To be sure, the safety of Europeans has been an important driver of European integration since its very beginning. In the aftermath of World War II, the European Coal and Steel Community was established not only to help economic reconstruction but also to prevent another conflict among European states. ${ }^{1}$ However, while this goal was initially achieved by indirect means of economic cooperation, over the past decade it has become a more explicit field of policy making, with ad hoc institutional bodies and programs not only in public health but also in disaster management, environmental protection, and regional military security such as the European Political and Security Committee, the European Union Military Committee, and the Civilian Planning and Conduct Capability. As Arjen Boin and colleagues (2006: 406) argued in a recent analysis, these developments suggest the emergence of a new policy space in the European Union: "What binds together the activities in that space is a common concern with protecting Europeans from harm."

As part of this process, moreover, the understanding of "European Community" has gained a more pronounced territorial meaning, with a shifting emphasis from internal security to the importance of monitoring and regulating the flows of people and substances between the internal space of the EU and the "external world." It is worth mentioning that this new level of policy discourse has emerged at a time of increasing concerns with border control and security, partly as a result of more porous borders after the collapse of the bipolar world order (Smith 2005). For example, in 2003 the European Council (2003: 8) adopted its first European Security Strategy "to promote a ring of well-governed countries to the East of

1. As the French foreign minister Robert Schumann claimed in 1950 in his declaration to the French National Assembly, "By pooling basic production and by instituting a new High Authority, whose decisions will bind France, Germany and other member countries, this proposal will lead to the realization of the first concrete foundation of a European federation indispensable to the preservation of peace" (Salmon and Nicoll 1997: 45). 
the Union and on the borders of the Mediterranean with whom we can enjoy close and cooperative relations," amid fears that the integration of acceding states could bring the EU closer to "troubled areas." Following this document, the council later established the European Agency for the Management of Operational Cooperation at the External Borders (Frontex), with the mandate to coordinate the border security operations of EU member countries (Frontex 2010). Similar to the early International Sanitary Conventions, Frontex envisioned a dynamic notion of EU borders as a semipermeable barrier that is open for commerce and "bona fide travellers" but closed for suspicious elements:

With 42,672 km of external sea borders and 8,826 km of land borders, the Schengen free-movement area comprises 25 countries (including a number of non-EU states) enabling free internal travel for nearly half a billion people across the continent, with 300,000 crossings at the external borders in 2009 alone. The Schengen zone is a unique global phenomenon and the number of people crossing its external borders is expected to keep rising. Within this context, Frontex's responsibility is . . to ensure that the EU's external borders remain permeable and efficient for bona fide travellers while being an effective barrier to cross-border crime." (Frontex 2010; emphasis added)

Recent disease surveillance and control programs bear witness to similar concerns with border control and security. After the latest rounds of enlargement, the EU's frontier shifted eastward to Ukraine and Belarus to lengthen its existing border with Russia. Following the collapse of the Soviet system and the rapid economic transition, these countries have experienced a significant increase in severe epidemics, including multi-drug resistant tuberculosis, HIV/AIDS, and diphtheria, partly as a result of weakened national health systems (Coker, Atun, and McKee 2004). In the wake of these developments, the EU's eastern frontier has become the new focus of public health policy and surveillance programs. In 1998, for example, Scandinavian countries initiated EpiNorth, a collaboration project with the Baltic states and Russia, to improve disease surveillance in the whole region and protect their territories from the spread of epidemics. A recent assessment of the ECDC, which has become a strategic partner of the project, stressed that "the overall aim of the expanded EpiNorth project was to improve communicable disease control and communication in Northern Europe and across the border to neighbouring countries in order to reduce the spread of such diseases and thus safeguard public health in the Community" (ECDC 2008b: 5). In line with this strategy, countries in southern Europe recently received support from the European 
Commission to develop the project EpiSouth for disease surveillance in the Mediterranean region and the Balkans. If taken together, these twin networks create a sort of surveillance "cushion" around the EU's frontier in which infectious diseases can be detected and monitored before they enter the union.

It must be noted, however, that such concerns with the protection of European space coexist with a parallel policy drive toward improved EU engagement in the wider landscape of global health. In the institutional history of the EU, this commitment was asserted as early as 1992 in the Maastricht Treaty, which stated that "the Community and the Member States shall foster cooperation with third countries and the competent international organisations in the sphere of public health" (European Community 1992). More recently, "Together for Health" (CEC 2007: 6) recognized that "in our globalised world it is hard to separate national or EU-wide actions from global policy" and thus stressed the need for more "coherence between internal and external health policies in attaining global health goals" and more support for external cooperation with low- and middle-income countries. In line with this agenda, since 2001 the European Commission has been a partner in the Global Health Security Initiative, an informal collaboration among the EU, Canada, France, Germany, Italy, Japan, Mexico, the United Kingdom, and the United States, established to strengthen global health preparedness and response to threats of bioterrorism and pandemic influenza. In the wake of avian influenza H5N1, moreover, the commission has developed and funded some projects with low- and middle-income countries, including a broad program for the prevention and control of highly pathogenic diseases in South Asia and Southeast Asia, with the assistance of WHO and in collaboration with the Association of South East Asian Nations (ASEAN) and the South Asian Association for Regional Cooperation. Finally, the existence of political platforms for cross-regional cooperation, such as the Asia-Europe Meeting (ASEM) process and the EU-ASEAN dialogue, might provide further institutional bases to support wider strategies on communicable disease control beyond EU borders.

\section{Protecting Europeans?}

Following this bird's-eye overview of the history of communicable disease control in Europe, there is room for reflection on past achievements, future challenges, and wider implications of this process of policy devel- 
opment. As we have seen, from the nineteenth century to the present the European space has been the focus of different forms of international cooperation. The adoption of international regulations and the establishment of permanent institutional bodies have contributed to the establishment of a European framework for communicable disease prevention and control. In the process, Europe has become the unit of analysis for public health assessments through the collection, collation, and interpretation of epidemiological data and other health indicators from a large number of countries. Periodic reports and studies from the WHO regional office have produced broad comparative analyses across European countries (see, e.g., Matic, Lazarus, and Donoghoe 2006) and in comparison with other world regions (see, e.g., Coker, Atun, and McKee 2008). Similar efforts at the EU level have further added to this stock of information. In particular, the consolidation of European surveillance networks and their integration under a single body (the ECDC) have created a common platform for data management and analysis, which can ensure more coherence and sustained funding of the chain of previous project-based arrangements, although epidemiological analyses at the European level may still be biased by differences in case definitions, medical consultation patterns, and reporting practices (ECDC 2008a).

However, the establishment of a supranational framework for communicable disease control in Europe still faces many challenges. While the EU has developed a solid architecture for disease monitoring and risk assessment, which can help national decision makers cope with the uncertainties of public health threats of international concern, so far EU recommendations on risk management have not always resulted in a coherent response across the EU, as illustrated by the recent case of H1N1 pandemic influenza. In June 2009, for example, the ECDC issued an evidence-based policy document advising national authorities to move from containment to mitigation strategies; however, most countries ignored this advice and insisted on containment strategies for many months (UK Health Protection Agency 2010a). Likewise, despite timely indications on target and priority groups for vaccination campaigns, national approaches varied greatly across the EU, with poor coverage and limited success in most countries (UK Health Protection Agency 2010b). These outcomes could be the result of various factors, including discrepancies in national "cultures" of public health, differential access to resources, or conflicts between member states reluctant to give up their autonomy in national governance and the imperatives of supranational integration. In addition, the sheer size of 
the EU - and the resulting problem of reaching consensus with a large number of stakeholders - poses further challenges to effective EU-wide coordination, especially in the middle of a crisis.

The failure to agree on establishing a European stockpile of antivirals illustrates other important limitations of the EU system vis-à-vis the autonomy of sovereign countries. In the wake of avian influenza H5N1, the European Commission developed plans to create a centrally managed pool of antivirals that could be distributed according to need in the event of a pandemic (CEC 2006). Regardless of the much debated public health benefits of vaccine and antiviral stockpiling (Keil, Schönhöfer, and Spelsberg 2011; Nicoll and Sprenger 2011), this project had the potential to redress imbalances between member states and thus illustrate the added value of EU policy in promoting solidarity. However, despite sustained efforts of the European Commission and several consultations, national health ministers eventually failed to reach an agreement - a prominent reminder that the implementation of large-scale public health interventions at the EU level is still very difficult given key differences in national needs, resources, policy prospects, and the lack of sufficient EU legal authority in health policy. Current plans to develop a mechanism for joint procurement of vaccines and antivirals might provide an alternative instrument to foster equitable access to resources, as this mechanism would enhance the negotiation power of participating authorities over pharmaceutical companies (CEC 2009). However, concerns have been raised that joint procurement should be carefully adapted to individual national needs, logistics, context, and legal framework (UK Health Protection Agency 2010b).

Finally, the relationship between the EU system and WHO is another key challenge and has the potential to affect future public health outcomes. Today WHO/Europe and the EU coexist as two independent institutional structures for communicable disease policy generation and program implementation in Europe. While considerable efforts and resources are expended in trying to find an aligned approach, duplication and inefficiencies remain a risk. During the H1N1pandemic, for example, member states' inconsistent reporting of case information to the EU Early Warning and Response System and WHO caused concern and frustration among participating authorities, resulting in higher administrative burdens. This situation has recently improved, at least in some areas where the two institutions have engaged in closer collaboration, such as preparedness plans on pandemic influenza. Further, in March 2011 the ECDC and WHO/ Europe signed a new agreement that replaces a former memorandum 
of understanding, identifying specific areas for collaboration, including implementing the International Health Regulations, pandemic preparedness and response, decreasing antimicrobial resistance, vaccination programs, and better coordination in disease surveillance (ECDC 2011). This renewed commitment is likely to improve coordination in some areas in which incoherence and duplications remain (Johnson, Meeyai, and Coker 2010). In this respect, the interchange of high-level staff between the two organizations and the proximity of WHO/Europe headquarters (Copenhagen) and the ECDC (Stockholm) may further facilitate joint actions. ${ }^{2}$

Yet to some extent the two organizations have different goals and approaches. First, their geopolitical coverage is very different (fifty-three member states of WHO/Europe versus twenty-seven of the European Union). ${ }^{3}$ Specifically, the inclusion of the Russian Federation and former Soviet states in the framework of WHO/Europe may result in considerably different policy strategies and priorities. Second, the activities of WHO/ Europe focus on needs and public health issues at the regional level, but nonetheless they respond to a universalistic vision of human health and are embedded in the overarching organization's overall structure, although some concerns have been raised in the past about the lack of WHO central control over regional offices (Godlee 1994; Yamey 2002). Likewise, WHO surveillance networks in Europe are part of a wider global structure of data collection and early warning systems. By contrast, EU policies on infectious diseases are first and foremost European. Similar to the early International Sanitary Conventions, their main goal is to protect the European space from diseases. As noted earlier, in recent years EU policy makers have been more aware of the need to strengthen the EU's voice in global health, as outlined in "Together for Health," including enhanced cooperation with WHO. However, current WHO regulations are not likely to foster closer EU engagement at the highest institutional level because the WHO statute is based on a system of national sovereignties, whereby membership is only open to states. At present, the European Commission has observer status at the World Health Assembly and is on the executive board and the regional committees but has no rights to vote.

2. In 2010 Zsuzsanna Jakab, the founding director of the ECDC, was appointed as the new director of the WHO Regional Office for Europe.

3. Some initiatives, however, have a broader coverage. For instance, the Early Warning and Response System also includes European Economic Community members that are not part of the EU (i.e., Iceland, Lichtenstein, and Norway). 


\section{Conclusions}

Different framings of "Europe," as well as contingent political and cultural contexts, have provided the background for health cooperation among European states. In the nineteenth and early twentieth centuries, the international sanitary conferences and conventions were shaped by the perceived need to insulate Europe from external threats without impediments to commerce and travel, as well as the imperative to protect national interests. After the end of World War II, the establishment of the WHO Regional Office for Europe provided a permanent institution to address public health issues at the regional level, in keeping with the wider spirit of cooperation that characterized European reconstruction. Finally, since the late 1980s the EU has become an increasingly important institutional actor for developing supranational mechanisms of communicable disease prevention and control as part of its new role, or at least part of its functions, as guardian of Europeans' health and safety.

The present European framework for communicable disease prevention and control is still fragmented across a range of diverse arrangements, including national policies and public health systems, bilateral agreements between countries, the WHO Regional Office for Europe, and the new EU system. In this evolving space, EU policies have the potential to add great value to the efforts of member states and international organizations charged with global surveillance, given the existence of a wide range of EU networks and connections in related policy areas and the unique experience of EU policy makers in supranational governance. To enhance effectiveness, however, the EU system should be sustained by a more articulated legal framework, able to more clearly improve and define the responsibilities of EU institutions in coordinating response to public health threats, not just surveillance, in relation to both member states and WHO. More importantly, the underlying philosophy of EU activities should be more coherent, as the current process of policy development tends to be driven by two contradictory postures. On the one hand, as we have seen, there is a perceived need for protecting an increasingly vulnerable European space, with an emphasis on external threats that is reminiscent of the early sanitary conventions. On the other hand, this approach coexists with a commitment to global health and the willingness to contribute to a wider context of human health and well-being.

The tension between these two different stances is not only crucial to the field of public health but reflects one of the most important issues for the future of European integration. Since the mid-1990s the question of 
European identity has become a key topic in the academic and political debate on the European Union. The point of departure is the idea that European integration needs a common set of values to ensure coherence and to endow its actions with legitimacy and meaning. This need has become more pressing since the Maastricht Treaty, which entrusts the community with new and stronger competences in a wide range of areas such as foreign policy, security, and defense. In contributing to the debate and suggesting directions for the future of Europe, some social theorists challenged the model of a European "super state" and recognized the cosmopolitan potential of the EU. For example, Gerard Delanty (2005: 416) has argued that Europe should become a "transnational polity" engaged with the realization of cosmopolitan values all over the world and "new kinds of connectivity through which the social is constituted beyond the limits of national societies." In a similar vein, Ulrich Beck (2006: 17) claimed that Europe should be defined by a "global sense, a sense of boundarylessness." Since the process of enlargement will probably come to an end and the contours of the EU frontier will stabilize in the social and political imaginary, these questions are likely to become more central in the debate on European integration. For the moment it is difficult to predict whether the EU will evolve into a super state, characterized by a marked territorial meaning, or become a more experimental cosmopolitan polity - although once again the force of global commerce may promote a global outlook over a "Fortress Europe" mentality. In any case, however, communicable disease control will be a critical policy field in which such choices will be both made and reflected.

\section{References}

Ackerknecht, E. H. 2009. "Anticontagionism between 1821 and 1867: The Fielding H. Garrison Lecture.” International Journal of Epidemiology 38, no. 1: 7-21. doi:10.1093/ije/dyn254.

Beck, U. 2006. The Cosmopolitan Vision. Cambridge: Polity.

Boin, A., M. Ekengren, and M. Rhinard. 2006. "Protecting the Union: Analysing an Emerging Policy Space." Journal of European Integration 28, no. 5: 405-21. doi:10.1080/07036330600979573.

Boudreau, F. G. 1935. "Health Work of the League of Nations." Milbank Memorial Fund Quarterly 13, no. 1: 3-22. doi:10.2307/3347906.

Briggs, A. 1961. "Cholera and Society in the Nineteenth Century." Past \& Present 19, no. 1: 76-96. doi:10.1093/past/19.1.76. 
Brock, T. D. 1999. Robert Koch: A Life in Medicine and Bacteriology. Washington, DC: American Society for Microbiology.

Coker, R., R. Atun, and M. McKee. 2004. "Health-Care System Frailties and Public Health Control of Communicable Disease on the European Union's New Eastern Border." Lancet 363, no. 9418: 1389-92. doi:10.1016/S0140-6736(04)16053-4.

.2008. Health Systems and the Challenge of Communicable Diseases: Experiences from Europe and Latin America. Maidenhead, UK: Open University Press.

Commission of the European Communities (CEC). 2005. "Healthier, Safer, More Confident Citizens: A Health and Consumer Protection Strategy.” COM(2005) 115 final. Brussels: CEC.

. 2006. "Influenza: Commissioner Kyprianou Regrets Failure to Agree on EU Anti-viral Stockpile.” Europa press release, June 2. europa.eu/rapid/pressReleases Action.do?reference $=\mathrm{IP} / 06 / 732$.

— 2007. "Together for Health: A Strategic Approach for the EU, 2008-2013." CEC White Paper. COM(2007) 630. Brussels: CEC.

_ 2009. "Commission Staff Working Document on Joint Procurement of Vaccine against Influenza A(H1N1).” SEC(2009) 1188 final. Brussels: CEC.

Danzon, M., and S. K. Litvinov. 1993. "Eurohealth Programme." World Health Statistics Quarterly 46: 153-7.

Delanty, G. 2005. "The Idea of a Cosmopolitan Europe: On the Cultural Significance of Europeanization.” International Review of Sociology 15, no. 3: 405-21. doi:10.1080/03906700500272434.

European Centre for Disease Prevention and Control (ECDC). 2008a. ECDC Strategic Multi-annual Programme, 2007-2013. Stockholm: ECDC.

_ 2008b. "EpiNorth Project: A Framework for Communicable Disease Surveillance, Communication, and Training in Northern Europe: Evaluation Report." Stockholm: ECDC.

2011. "ECDC and WHO/Europe Have Signed a New Administrative Agreement." Press release, March 29. ecdc.europa.eu/en/press/news/Lists/News/ECDC _DispForm.aspx?List=32e43ee8\%2De230\%2D4424\%2Da783\%2D85742124029 a\&ID=420 (accessed October 2011).

European Community. 1992. Maastricht Treaty. Article 152. eur-lex.europa.eu/Lex UriServ/LexUriServ.do?uri=CELEX:12002E152:EN:HTML.

European Council. 2003. A Secure Europe in a Better World: European Security Strategy. Brussels: EU Institute for Security Studies.

European Parliament and EU Council. 1998. "Decision 2119/98/EC of the European Parliament and of the Council of 24 September 1998 Setting Up a Network for the Epidemiological Surveillance and Control of Communicable Diseases in the Community." Official Journal of the European Communities L 268 (October).

- 2004. "Regulation (EC) No 851/2004 of the European Parliament and of the Council of 21 April 2004 Establishing a European Centre for Disease Prevention and Control." Official Journal of the European Union. L 142.

Fidler, D. 2005. "From International Sanitary Conventions to Global Health Security: The New International Health Regulations." Chinese Journal of International Law 4, no. 2: 325-92. doi:10.1093/chinesejil/jmi029. 
Fleming, D. M., and J. M. Cohen. 1996. "Experience of European Collaboration in Influenza Surveillance in the Winter of 1993-1994." Journal of Public Health Medicine 18, no. 2: 133-42. doi:10.1093/oxfordjournals.pubmed.a024472.

Fleming, D. M., J. van der Velden, and W. J. Paget. 2003. "The Evolution of Influenza Surveillance in Europe and Prospects for the Next Ten Years." Vaccine 21, no. 16: 1749-53. doi:10.1016/S0264-410X(03)00066-5.

Frontex. 2010. “Origin.” www.frontex.eu.int/origin_and_tasks/origin/ (accessed October 2011).

Gensini, G. F., M. Yacoub, and A. Conti. 2004. "The Concept of Quarantine in History: From Plague to SARS." Journal of Infection 49, no. 4: 257-61. doi:10.1016/j .jinf.2004.03.002.

Godlee, Fiona. 1994. "The World Health Organisation: The Regions — Too Much Power, Too Little Effect.” BMJ (Clinical Research Ed.) 309, no. 6968: 1566-70. doi:10.1136/bmj.309.6968.1566.

Greer, S. L. 2008. "Choosing Paths in European Union Health Services Policy: A Political Analysis of a Critical Juncture." Journal of European Social Policy 18, no. 3: 219-31. doi:10.1177/0958928708091056.

Guglielmetti, P., et al. 2006. "The Early Warning and Response System for Communicable Diseases in the EU: An Overview from 1999 to 2005." Eurosurveillance 11, no. 12: 215-20.

Hays, J. N. 2005. Epidemics and Pandemics: Their Impacts on Human History. Santa Barbara, CA: ABC-CLIO.

Howard-Jones, N. 1950. "Origins of International Health Work." British Medical Journal 1, no. 4661: 1032-7. doi:10.1136/bmj.1.4661.1032.

1975. The Scientific Background of the International Sanitary Conferences, 1851-1938. Geneva: World Health Organization.

Huber, Valeska. 2006. "The Unification of the Globe by Disease? The International Sanitary Conferences on Cholera, 1851-1894." Historical Journal (Cambridge, England) 49, no. 2: 453-76. doi:10.1017/S0018246X06005280.

Johnson, H., A. Meeyai, and R. Coker. 2010. "Potential for Greater Coherence in European Influenza Surveillance.” European Journal of Public Health 20, no. 5: 488-9. doi:10.1093/eurpub/ckq124.

Keil, U., P. Schönhöfer, and A. Spelsberg. 2011. "The Invention of the Swine-Flu Pandemic.” European Journal of Epidemiology 26, no. 3: 187-90. doi:10.1007/s10654 -011-9573-6.

Lamping, W., and M. Steffen. 2009. "European Union and Health Policy: The 'Chaordic' Dynamics of Integration.” Social Science Quarterly 90, no. 5: 1361-79. doi:10.1111/j.1540-6237.2009.00659.x.

League of Nations. 1920. Covenant of the League of Nations, Article 23. avalon.law yale.edu/20th_century/leagcov.asp.

Lee, K. 2009. The World Health Organization (WHO). Oxon, UK: Routledge.

Liverani, M., P. Hanvoravongchai, and R. Coker. 2012. "Communicable Diseases and Governance: A Tale of Two Regions." Global Public Health 7, no. 6: 574-87. doi:10.1080/17441692.2012.685487.

MacLehose, L., M. McKee, and J. Weinberg. 2002. "Responding to the Challenge of 
Communicable Disease in Europe.” Science 295, no. 5562: 2047-50. doi:10.1126/ science. 1070025 .

Maglen, K. 2003. "Politics of Quarantine in the Nineteenth Century." Journal of the American Medical Association 290, no. 21: 2873. doi:10.1001/jama.290.21.2873.

Matic, S., J. V. Lazarus, and M. C. Donoghoe, eds. 2006. HIV/AIDS in Europe: Moving from Death Sentence to Chronic Disease Management. Copenhagen: WHO Regional Office for Europe.

McKee, M., L. MacLehose, and E. Nolte, eds. 2004. Health Policy and European Union Enlargement. Maidenhead, UK: Open University Press.

McKee, M., and E. Mossialos. 2006. "Health Policy and European Law: Closing the Gaps." Public Health 120(Suppl.): 16-21. doi:10.1016/j.puhe.2006.07.008.

Nicoll, A., and M. Sprenger. 2011. "Learning Lessons from the 2009 Pandemic: Putting Infections in Their Proper Place.” European Journal of Epidemiology 26, no. 3: 191-4. doi:10.1007/s10654-011-9575-4.

Reintjes, R. 2008. "International and European Responses to the Threat of Communicable Diseases." In Coker, Atun, and McKee 2008: 141-53.

Salmon, T., and W. Nicoll. 1997. Building European Union: A Documentary History and Analysis. Manchester, UK: Manchester University Press.

Smith, K. 2005. "The Outsiders: The European Neighbourhood Policy." International Affairs 81, no. 4: 757-73. doi:10.1111/j.1468-2346.2005.00483.x.

UK Health Protection Agency. 2010a. Assessment Report on the EU-Wide Response to Pandemic (H1N1) 2009. Brussels: European Commission.

. 2010b. Assessment Report on the EU-wide Pandemic Vaccine Strategies. Brussels: European Commission.

World Health Organization (WHO). [1948]. "Constitution of the World Health Organization.” Geneva: WHO. apps.who.int/gb/bd/PDF/bd47/EN/constitution-en.pdf. 1951. International Sanitary Regulations. Geneva: WHO.

1958. The First Ten Years of the World Health Organization. Geneva: WHO. 1978. "Declaration of Alma-Ata." Geneva: WHO. www.who.int/hpr/NPH/ docs/declaration_almaata.pdf. 2010. Sixty Years of WHO in Europe. Geneva: WHO.

Yamey, G. 2002. "WHO in 2002: Have the Latest Reforms Reversed WHO's Decline?" BMJ (Clinical Research Ed.) 325, no. 7372: 1107-12. doi:10.1136/bmj.325.7372.1107. 